\title{
DESAIN PEMBELAJARAN DARING MATA KULIAH RANGKAIAN DIGITAL BERBANTUAN SIMULASI
}

\author{
Ahsan Muafa \\ Desain Komunikasi Visual, Fakultas Teknik \\ Universitas Maarif Hasyim Latif, Sidoarjo, Indonesia \\ e-mail : ahsanmuafa@dosen.umaha.ac.id \\ Diterima: 30 April 2019. Disetujui : 15 Juni 2019. Dipublikasikan : 30 Juni 2019 \\ (C)2019 -TESJ Fakultas Teknik Universitas Maarif Hasyim Latif. Ini adalah artikel dengan \\ akses terbuka di bawah lisensi CC BY 4.0 (https://creativecommons.org/licenses/by/4.0/)
}

\begin{abstract}
ABSTRAK
Lulusan program studi vokasi di tuntut siap bekerja di industry sesuai bidangnya. Oleh karena itu lulusan program studi vokasi perlu dibekali dengan pengalaman menyelesaikan permasalahan industri. Kebijakan pembelajaran jarak jauh secara daring telah mengurangi intensitas kegiatan untuk memperoleh pengalaman tersebut secara langsung. Mengetahui efektifitas desain perangkat pembelajaran berbantuan simulasi Komputer secara daring untuk meningkatkan kompetensi praktis mahasiswa dalam menyelesaikan permasalahan industri. Dengan desain pembelajaran ini diharapkan mampu meningkatkan kompetensi, sehingga ketika lulus akan memiliki kompetensi yang sesuai dengan kebutuhan industri. Desain pengembangan perangkat pembelajaran menggunakan four D model. Tahap persiapan digunakan untuk mendefinisikan permasalahan rangkaian digital, tahap kedua merancang perangkat pembelajaran daring dan tahap ketiga membuat perangkat pembelajaran mata kuliah rangkaian digital. Hasil penelitian menunjukkan bahwa pengembangan perangkat pembelajaran: (1) RPS memenuhi kriteria sangat valid (nilai kevalidan 3,29), LKM daring memenuhi kriteria sangat valid (nilai kevalidan 3,36), dan LP Daring memenuhi kriteria sangat valid (nilai kevalidan 3,6); (2) keterlaksanaan pembelajaran tergolong baik dengan rata-rata 3,2; (3) Perangkat pembelajaran dinyatakan efektif dengan persentase $83,33 \%$ mahasiswa berada pada kategori terampil atau sangat terampil. Hasil belajar mahasiswa mencapai ketuntasan klasikal dengan persentase $80,56 \%$ untuk aspek pengetahuan dan $77,78 \%$ untuk aspek keterampilan.
\end{abstract}

Kata kunci : Daring, Four D model, Perangkat Pembelajaran, Simulasi Komputer

\section{PENDAHULUAN}

Tujuan utama pendidikan pada awalnya untuk pencerahan. Pendidikan hanya diorientasikan pada pengembangan akal budi manusia. Dengan adanya perkembangan teknologi dan ilmu pengetahuan, termasuk terjadinya revolusi industri yang menghasilkan atau melahirkan spesialisasi maka dunia pendidikan bergeser dari orientasi akal budi ke arah profesionalisme.

Lulusan Perguruan Tinggi ditengarai belum cukup dibekali profesionalisme yang diperlukan. Mereka hanya dibekali dengan muatan kognisi saja. Dengan kenyataan masih belum terpenuhinya kebutuhan stakeholder tersebut maka dapat disimpulkan bahwa masih ada distorsi antara hasil pembelajaran mahasiswa dengan kebutuhan stakeholder. Salah satu tindakan yang dapat dilakukan dalam rangka menyelaraskan kebutuhan stakeholder dan pencapaian kompetensi mahasiswa adalah mengevaluasi serta mengembangkan perangkat pembelajaran agar pembelajaran dapat menghasilkan kompetensi profesional mahasiswa yang sesuai dengan kebutuhan stakeholder.
Sehingga, pelaksanaan pembelajaran memiliki standar baku sesuai karakteristik program studi dan dapat memenuhi kebutuhan stakeholder.

Untuk memenuhi kebutuhan stakeholder tersebut maka pendidikan harus sesuai dengan standar pendidikan Indonesia. Pada sistem pendidikan nasional Indonesia, pendidikan ahli madya merupakan pendidikan vokasi yang mempersiapkan mahasiswanya untuk mendapatkan lebih banyak ketrampilan praktis daripada teoritis. Persentase waktu untuk mendapatkan ketrampilan tersebut 70\% ketrampilan praktis dan 30\% teori. Salah satu unit pendidikan vokasi pada jenjang diploma 3 adalah Program Studi (Prodi) Teknik Komputer Universitas Maarif Hasyim Latif (UMAHA) Sidoarjo. Prodi Teknik Komputer UMAHA mempunyai tugas utama mempersiapkan mahasiswa yang mampu menerapkan ilmu komputer untuk membantu menyelesaikan masalah yang berhubungan dengan proses industri.

Untuk menyiapkan lulusan dengan kompetensi tersebut, UMAHA melaksanakan perkuliahan sesuai dengan standar yang ditentukan pemerintah. Pada PP Nomor 19 Tahun 
2005 tentang Standar Nasional Pendidikan dikatakan bahwa pembelajaran harus berlangsung interaktif, inspiratif, menyenangkan, menantang, memotivasi peserta didik untuk berpartisipasi aktif, serta memberikan ruang yang cukup bagi prakarsa, kreatifitas, dan kemandirian sesuai dengan bakat, minat, dan perkembangan fisik serta psikologis peserta didik. Agar pembelajaran ideal sesuai dengan definisi dan kriteria tersebut maka pada tiap proses pembelajaran diperlukan suatu pendukung berupa media pembelajaran.

Media dalam pembelajaran dapat berperan sebagai penyalur pesan, pemotivasian, penciptaan suasana, sekaligus sebagai sumber belajar. Dengan menerapkan penggunaan media pembelajaran pada tiap proses belajar mengajar diharapkan dapat memotivasi mahasiswa untuk terus belajar dan dapat menjadi perantara penyampaian pesan pembelajaran dengan benar.

Rangkaian digital merupakan salah satu mata kuliah yang wajib diambil setiap mahasiswa Prodi Teknik Komputer UMAHA. Kajian kuliah terdiri atas teori dan praktek yang berorientasi membantu mahasiswa dalam memperoleh kompetensi pemahaman materi tentang bagaimana merancang sebuah rangkaian digital untuk merancang sebuah otomasi sistem. Penguasaan pengetahuan ini akan sangat berguna bagi mahasiswa untuk bisa bersaing di dunia industri yang pada masa kini berkembang ke arah otomatisasi. Dari tingkat pentingnya mata kuliah Rangkaian digital ini maka penelitian sangat diperlukan. Penelitian diperlukan untuk menjamin bahwa pelaksanaan pembelajaran yang diwujudkan dalam kegiatan perkuliahan dapat meningkatkan peran aktif mahasiswa. Peran aktif mahasiswa dapat diupayakan dengan membuat perangkat pembelajaran yang relevan dan cocok dengan materi yang dipelajari. Sehingga, perangkat pembelajaran yang dibuat dapat meningkatkan kompetensi profesional mahasiswa serta sesuai dengan kebutuhan stakeholder.

Berdasarkan latar belakang yang telah dikemukakan di atas maka dapat dirumuskan permasalahan bagaimana kelayakan, efektifitas dan pengaruh penerapan pengembangan perangkat pembelajaran mata kuliah rangkaian digital berbantuan media simulasi komputer terhadap pencapaian kompetensi mahasiswa di Prodi Teknik Komputer UMAHA.

\section{METODE PENELITIAN}

Penelitian ini merupakan penelitian pengembangan karena mengembangkan perangkat pembelajaran yang berupa Rencana Pembelajaran Semester (RPS), Lembar Kerja Mahasiswa (LKM), dan Lembar Penilaian (LP)
Subjek dalam penelitian ini adalah mahasiswa Prodi Teknik Komputer UMAHA angkatan 2018 yang berjumlah 20 mahasiswa, yang memprogram mata kuliah rangkaian digital.

Rancangan penelitian ini menggunakan rancangan penelitian pengembangan perangkat dengan model four- $D$. Model ini terdiri atas empat tahap pengembangan, yaitu tahap pendefinisian (define), tahap perancangan (design), tahap pengembangan (develop), dan tahap pendiseminasian/penyebaran (disseminate) (Trianto, 2003). Model ini dipilih karena langkah pengembangannya mudah dipahami serta urutannya lebih rinci dan sistematis. Tetapi, pada penelitian ini, hanya dilakukan sampai pada tahap pengembangan (Develop), sedangkan untuk tahap penyebaran (Disseminate), tidak dilakukan. Secara ringkas model pengembangan four- $D$ dijelaskan dalam Gambar 1.

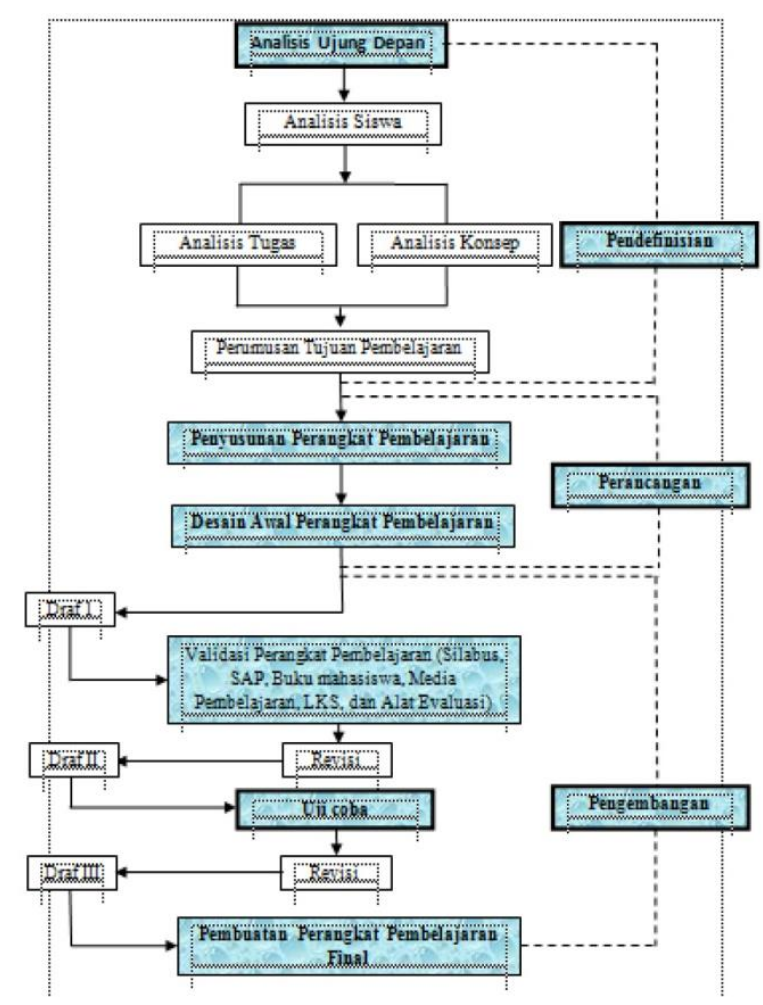

Gambar 1. Rancangan Penelitian Pengembangan

Yang pertama tahap define. Tujuan tahap ini adalah menetapkan dan mendefinisikan syaratsyarat pembelajaran. Dalam menentukan dan menetapkan syarat-syarat pembelajaran diawali dengan analisis tujuan dari batasan materi yang dikembangkan perangkatnya. Tahap ini meliputi lima langkah pokok, yaitu a) analisis ujung depan, b) analisis mahasiswa, c) analisis tugas, d) analisis konsep, dan e) perumusan tujuan pembelajaran (Trianto, 2003).

Selanjutnya tahap design. Tahap perancangan meliputi beberapa kegiatan seperti penyusunan silabus, RPS sesuai dengan silabus, pemilihan buku mahasiswa yang didasarkan pada 
kompetensi pembelajaran rangkaian digital, Pemilihan media pembelajaran yang didasarkan pada kompetensi pembelajaran rangkaian digital, Penentuan LKM yang didasarkan pada kompetensi pembelajaran rangkaian digital, Penyusunan LP yang didasarkan pada kompetensi pembelajaran rangkaian digital dan perencanaan perangkat pembelajaran yang didasarkan pada kompetensi pembelajaran rangkaian digital.

Sedangkan pada tahap develop, merupakan kelanjutan dari tahap perancangan yang menghasilkan "prototype" perangkat pembelajaran rangkaian digital. Tahap ini menghasilkan draf 1. Selanjutnya, pada tahap pengembangan ini nantinya akan dilakukan validasi terhadap draf 1 perangkat pembelajaran yang meliputi beberapa hal antara lain kelayakan Isi Perangkat Pembelajaran, kelayakan Penyajian Perangkat Pembelajaran dan kelayakan Bahasa Perangkat Pembelajaran.

Validasi dilakukan oleh tim validator. Rekomendasi dari tim validator menjadi rujukan untuk perbaikan, sehingga menghasilkan draf 2 perangkat pembelajaran. Langkah selanjutnya uji coba draf 2. Uji coba ini dilaksanakan pada mahasiswa yang terdiri dari pemakai perangkat pembelajaran yaitu sejumlah 20 mahasiswa dan dosen pengampu.

Data penelitian ini berasal dari: 1) kualitas pengembangan perangkat pembelajaran yang berorientasi model pembelajaran kooperatif, 2) efektivitas pengembangan perangkat pembelajaran yang berorientasi model pembelajaran kooperatif, yang beberapa datanya mencakup tentang (a) keterlaksanaan perangkat pembelajaran rangkaian digital, (b) aktivitas mahasiswa selama pelaksanaan kegiatan pembelajaran rangkaian digital , dan (c) tanggapan mahasiswa terhadap perangkat pembelajaran rangkaian digital serta (d) hasil belajar mahasiswa pada pokok bahasan shift register.

Untuk memperoleh data tentang proses pengembangan perangkat pembelajaran rangkaian digital yang berorientasi pada model pembelajaran kooperatif, digunakan teknik validasi dan observasi. Validasi dilaksanakan oleh tim validator sedangkan observasi dilakukan oleh pengamat.

Instrumen penelitian yang digunakan dalam penelitian ini meliputi validasi atas silabus, RPS, LKM, media pembelajaran dan lembar penilaian oleh validator serta observasi terhadap efektivitas perangkat pembelajaran yang terdiri atas keterlaksanaan RPS dan hasil pre-test dan post-test mahasiswa yang kemudian dinilai dengan menggunakan uji signifikansi.

Analisis data dilakukan dengan teknik analisis deskriptif kuantitatif untuk skor para penilai/validator perangkat pembelajaran (teman sejawat/sesama dosen).
Kriteria yang dijadikan acuan untuk menentukan berkualitas atau tidak berkualitasnya perangkat pembelajaran maka digunakan pedoman penilaian skala linkert.

Hasil analisis lembar skor hasil validasi digunakan untuk mengetahui kelayakan/kualitas perangkat pembelajaran yang dikembangkan dengan menggunakan interpretasi skor tersebut kualitas perangkat pembelajaran dalam pembelajaran rangkaian digital berkualitas apabila skor/ presentasenya $\geq 61 \%$.

Analisis data tentang efektivitas perangkat pembelajaran yang berorientasi pada pembelajaran kooperatif yang dilakukan dengan teknik analisis deskriptif untuk menentukan skor para penilai/validator dan pemakai produk perangkat pembelajaraan. Data dari mahasiswa dalam hal ini berupa angket dianalisis dengan analisis deskriptif kualitatif.

Untuk mengetahui efektivitas perangkat pembelajaran rangkaian digital, digunakan tes analisis data dengan tes uji signifikansi. Efektivitas penerapan (uji coba) perangkat pembelajaran rangkaian digital yang berorientasi pada pembelajaran daring, dalam hal ini efektivitas diindikatori oleh beberapa analisis dalam proses penggunaan perangkat pembelajaran di dalam kaitannya dengan proses berlangsungnya kegiatan atau proses belajar mengajar.

Untuk ketuntasan hasil belajar, dalam penelitian ini dilakukan tes hasil belajar. Dengan demikian peneliti bertindak langsung dengan mengobservasi. Observasi dilakukan sebanyak dua kali yaitu sebelum penggunaan perangkat pembelajaran dan sesudah penggunaan perangkat pembelajaran. Observasi yang dilakukan sebelum pengembangan perangkat pembelajaran rangkaian digital $\left(\mathrm{O}_{1}\right)$ disebut pretest dan observasi setelah pengembangan perangkat pembelajarn rangkaian digital $\left(\mathrm{O}_{2}\right)$ disebut sebagai post-test. Perbedaan antara $\mathrm{O}_{1}$ dan $\mathrm{O}_{2}$ yakni $\mathrm{O}_{2}-\mathrm{O}_{1}$ diasumsikan merupakan efek dari treatment atau eksperimen (Suharsimi, 2006).

\section{HASIL DAN PEMBAHASAN}

Hasil validasi oleh validator terangkum pada Tabel 1.

Secara umum, hasil penilaian kualitas perangkat pembelajaran oleh validator, perangkat pembelajaran yang telah dibuat mendapatkan skor rata-rata 0,8172. Ini berarti perangkat pembelajaran yang telah dibuat telah memenuhi syarat dan masuk kategori sangat berkualitas $(\geq 81$ $\%)$.

Untuk memperoleh data tentang efektivitas perangkat pembelajaran digunakan instrumen non tes berupa lembar observasi tentang 
Tabel 1. Hasil Validasi Pengembangan Perangkat

\begin{tabular}{|c|c|c|c|c|}
\hline \multirow{2}{*}{ No } & \multirow{2}{*}{ Aspek penilaian } & \multicolumn{3}{|c|}{ Hasil Penilaian Validator } \\
\hline & & 1 & 2 & 3 \\
\hline \multirow[t]{15}{*}{1} & Komponen Silabus, RPS dan LP & & & \\
\hline & a. Identitas lembaga & 5 & 5 & 4 \\
\hline & b. Alokasi waktu sesuai tuntutan kurikulum & 5 & 5 & 4 \\
\hline & c. Standard kompetensi sesuai kurikulum & 5 & 5 & 4 \\
\hline & d. Kompetensi dasar sesuai kurikulum & 5 & 5 & 4 \\
\hline & e. Indikator merupakan penjabaran Capaian Akhir (CA) dituliskan secara operasional & 4 & 4 & 4 \\
\hline & f. Tujuan pembelajaran sesuai indikator dan dituliskan secara operasional & 4 & 4 & 4 \\
\hline & g. Materi pembelajaran sesuai dengan Capaian Pembelajaran dan CA & 5 & 5 & 5 \\
\hline & h. Metode pembelajaran sesuai karakteristik materi & 4 & 4 & 4 \\
\hline & i. Alat dan sumber belajar menunjang kegiatan pembelajaran & 5 & 5 & 3 \\
\hline & j. Langkah-langkah kegiatan yang dilakukan meliputi : & & & \\
\hline & 1) Pendahuluan & 4 & 4 & 4 \\
\hline & 2) Kegiatan inti & 4 & 4 & 4 \\
\hline & 3) Penutup & 4 & 4 & 4 \\
\hline & k. Penilaian sesuai dengan tujuan & 4 & 4 & 4 \\
\hline \multirow[t]{6}{*}{2} & Relevansi & & & \\
\hline & a. Relevansi antara RPS dengan Silabus & 5 & 5 & 5 \\
\hline & b. Relevansi antara RPS dengan Tujuan pembelajaran & 5 & 5 & 5 \\
\hline & c. Relevansi antara RPS dengan LKM & 4 & 4 & 4 \\
\hline & d. Struktur kalimat/bahasa yang digunakan dalam RPS dan LKM & 3 & 3 & 3 \\
\hline & e. Format Silabus, RPS dan LKM & 4 & 4 & 4 \\
\hline \multirow[t]{8}{*}{3} & Penulisan SAP & & & \\
\hline & a. Memperhatikan pengetahuan awal mahasiswa tentang Komponen Pengaturan Motor & 5 & 4 & 5 \\
\hline & b. Merencanakan proses pembelajaran student center & 5 & 4 & 5 \\
\hline & $\begin{array}{l}\text { c. Merencanakan proses pembelajaran praktek dan teori lebih mudah dengan menggunakan } \\
\text { simulasi komputer }\end{array}$ & 5 & 4 & 5 \\
\hline & $\begin{array}{l}\text { d. Menekankan kegiatan mahasiswa untuk bekerja sama dalam menciptakan pembelajaran } \\
\text { yang lebih baik }\end{array}$ & 4 & 4 & 4 \\
\hline & $\begin{array}{l}\text { e. Mengembangkan ketrampilan membuat simulasi untuk memecahkan permasalahan } \\
\text { pengaturan motor }\end{array}$ & 5 & 4 & 5 \\
\hline & f. Merencanakan proses pembelajaran dalam suasana demokratis dan interaktif & 4 & 4 & 4 \\
\hline & g. Merencanakan umpan balik untuk penilaian diri & 3 & 3 & 3 \\
\hline \multirow[t]{25}{*}{4} & Penilaian LKM & & & \\
\hline & a. Petunjuk dinyatakan dengan jelas & 5 & 5 & 5 \\
\hline & b. Mencantumkan tujuan pembelajaran & 5 & 5 & 5 \\
\hline & c. Materi LKM sesuai dengan tujuan pembelajaran di LKM dan RPS & 5 & 5 & 5 \\
\hline & d. Keluasan materi & 4 & 4 & 4 \\
\hline & e. Kedalaman materi & 3 & 3 & 3 \\
\hline & f. Akurasi fakta & 4 & 3 & 4 \\
\hline & g. Kebenaran konsep & 4 & 4 & 4 \\
\hline & h. Kebenaran prinsip atau hukum & 4 & 4 & 4 \\
\hline & i. Kesesuaian dengan perkembangan ilmu & 4 & 4 & 4 \\
\hline & j. Akurasi teori & 4 & 3 & 4 \\
\hline & k. Akurasi prosedur atau metode & 4 & 4 & 4 \\
\hline & 1. Menumbuhkan kreativitas & 4 & 4 & 4 \\
\hline & m. Menumbuhkan rasa ingin tahu & 4 & 4 & 4 \\
\hline & n. Mengembangkan kecakapan personal & 4 & 4 & 4 \\
\hline & o. Mengembangkan kecakapan sosial & 4 & 4 & 4 \\
\hline & p. Mengembangkan kecakapan akademis & 4 & 4 & 4 \\
\hline & q. Mengembangkan kecakapan vokasional & 5 & 4 & 5 \\
\hline & r. Mendorong untuk mencari informasi lebih lanjut & 3 & 3 & 3 \\
\hline & s. Menyajikan contoh-contoh konkrit dari lingkungan lokal/nasional/regional/internasional & 3 & 3 & 3 \\
\hline & t. Urutan kerja & 5 & 4 & 5 \\
\hline & u. Keterbacaan bahasa dalam prosedur & 4 & 4 & 4 \\
\hline & v. Kesesuian pertanyaan dengan tujuan pembelajaran di LKM dan RPS & 4 & 4 & 4 \\
\hline & w. Pertanyaan mendukung konsep & 3 & 3 & 3 \\
\hline & x. Keterbacaan bahasa dalam pertanyaan & 4 & 3 & 4 \\
\hline \multirow[t]{6}{*}{5} & Penilaian Media & & & \\
\hline & a. Kecocokan media dengan materi ajar & 5 & 4 & 5 \\
\hline & b. Kemudahan pengoperasian program & 3 & 3 & 3 \\
\hline & c. Kecocokan antara media dan kemampuan komputer & 4 & 4 & 4 \\
\hline & d. Kecukupan waktu operasional media dalam KBM & 3 & 3 & 3 \\
\hline & e. Petunjuk penunjang operasional komputer & 4 & 4 & 4 \\
\hline \multirow{3}{*}{\multicolumn{2}{|c|}{$\begin{array}{c}\text { Total Skor Validasi } \\
\text { Skor Maksimal } \\
\text { Prosentase rata-rata }\end{array}$}} & 226 & 216 & 220 \\
\hline & & 270 & 270 & 270 \\
\hline & & & 0,8172 & \\
\hline
\end{tabular}

keterlaksanaan perangkat pembelajaran, lembar aktivitas, lembar respon mahasiswa, dan instrumen tes berupa lembar penilaian hasil pretest dan post-test mahasiswa, yang kemudian dinilai dengan menggunakan uji signifikansi. Hasil observasi keterlaksanaan perangkat pembelajaran dapat dilihat pada Tabel 2 . 
Tabel 2. Rekapitulasi Keterlaksanaan Perangkat

\begin{tabular}{|c|c|c|c|}
\hline & \multirow[t]{2}{*}{ Kategori Keterlaksanaan } & \multicolumn{2}{|c|}{$\begin{array}{c}\text { Hasil } \\
\text { Pengamatan }\end{array}$} \\
\hline & & 1 & 2 \\
\hline \multirow[t]{4}{*}{1.} & $\begin{array}{l}\text { Pendahuluan } \\
\text { a. Memotivasi mahasiswa tentang } \\
\text { manfaat menguasai materi ajar }\end{array}$ & 1 & 1 \\
\hline & $\begin{array}{l}\text { b. Mahasiswa memahami sepenggal video } \\
\text { rangkaian digital }\end{array}$ & 1 & 1 \\
\hline & c. Membangun pengetahuan awal & 1 & 1 \\
\hline & $\begin{array}{l}\text { d. Menjelaskan dengan jelas tujuan } \\
\text { pembelajaran }\end{array}$ & 1 & 1 \\
\hline \multirow[t]{7}{*}{2.} & $\begin{array}{l}\text { Kegiatan inti } \\
\text { a. Menyajikan informasi komponen } \\
\text { rangkaian digital }\end{array}$ & 1 & 1 \\
\hline & $\begin{array}{l}\text { b. Mahasiswa memahami Program } \\
\text { simulasi }\end{array}$ & 1 & 0 \\
\hline & $\begin{array}{l}\text { c. Mengorganisasikan mahasiswa untuk } \\
\text { mengerjakan LKM }\end{array}$ & 1 & 1 \\
\hline & $\begin{array}{l}\text { d. Mendemonstrasikan cara membuat } \\
\text { rangkaian simulasi dan menjalankan } \\
\text { program. }\end{array}$ & 1 & 1 \\
\hline & $\begin{array}{l}\text { e. Membimbing mahasiswa untuk } \\
\text { mengecek kebenaran simulasi }\end{array}$ & 1 & 1 \\
\hline & $\begin{array}{l}\text { f. Mengecek pemahaman dan memberi } \\
\text { umpan balik hasil pekerjaan } \\
\text { mahasiswa. }\end{array}$ & 1 & 1 \\
\hline & $\begin{array}{l}\text { g. Memberi latihan lanjutan dengan } \\
\text { memberi latihan simulasi untuk } \\
\text { komponen lain }\end{array}$ & 0 & 0 \\
\hline \multirow[t]{7}{*}{3.} & $\begin{array}{l}\text { Penutup } \\
\text { a. Dosen menyimpulkan kegiatan atau } \\
\text { hasil pembelajaran }\end{array}$ & 1 & 1 \\
\hline & $\begin{array}{l}\text { b. Menjelaskan hal-hal yang sulit atau } \\
\text { kurang dipahami mahasiswa }\end{array}$ & 1 & 1 \\
\hline & $\begin{array}{l}\text { c. Dosen memberikan penghargaan pada } \\
\text { mahasiswa yang kinerjanya bagus }\end{array}$ & 0 & 0 \\
\hline & $\begin{array}{l}\text { d. Memberikan tugas yang akan } \\
\text { dikerjakan dirumah agar melatih } \\
\text { mahasiswa lebih terampil }\end{array}$ & 1 & 1 \\
\hline & Jumlah & 13 & 12 \\
\hline & Persentase & 15 & 15 \\
\hline & Rata-rata & \multicolumn{2}{|c|}{0,83} \\
\hline
\end{tabular}

Secara umum, keterlaksanaan langkah pembalajaran selama proses belajar mengajar dikelas dapat dilaksanakan dengan sangat baik $(0,83)$. Ini berarti dapat dikatakan bahwa perangkat pembelajaran yang dikembangkan dapat dilaksanakan dengan baik. Sehingga, perangkat pembelajaran dapat dikatakan efektif untuk digunakan.

Sedangkan aktivitas dosen dan mahasiswa selama proses belajar mengajar dapat dilihat pada Tabel 3.

Berdasarkan hasil pengamatan pada Tabel 3, secara umum, aktivitas dosen selama proses belajar mengajar masuk dalam kategori baik, dengan perolehan skor pengamatan rata-rata 0,79 . Dari hasil ini dapat dikatakan bahwa perangkat pembelajaran rangkaian digital yang digunakan oleh dosen selama proses belajar mengajar efektif digunakan oleh dosen pengampu.

Selanjutnya untuk aktivitas mahasiswa selama proses pembelajaran dapat dilihat pada Tabel 4.

Berdasarkan data Tabel 4, dapat dikatakan bahwa aktivitas belajar mahasiswa selama proses belajar mengajar masuk dalam kategori sangat baik (skor 84\%). Ini berarti bahwa perangkat pembelajaran yang digunakan efektif bagi mahasiswa yang menggunakannya.

Tabel 3. Aktivitas dosen

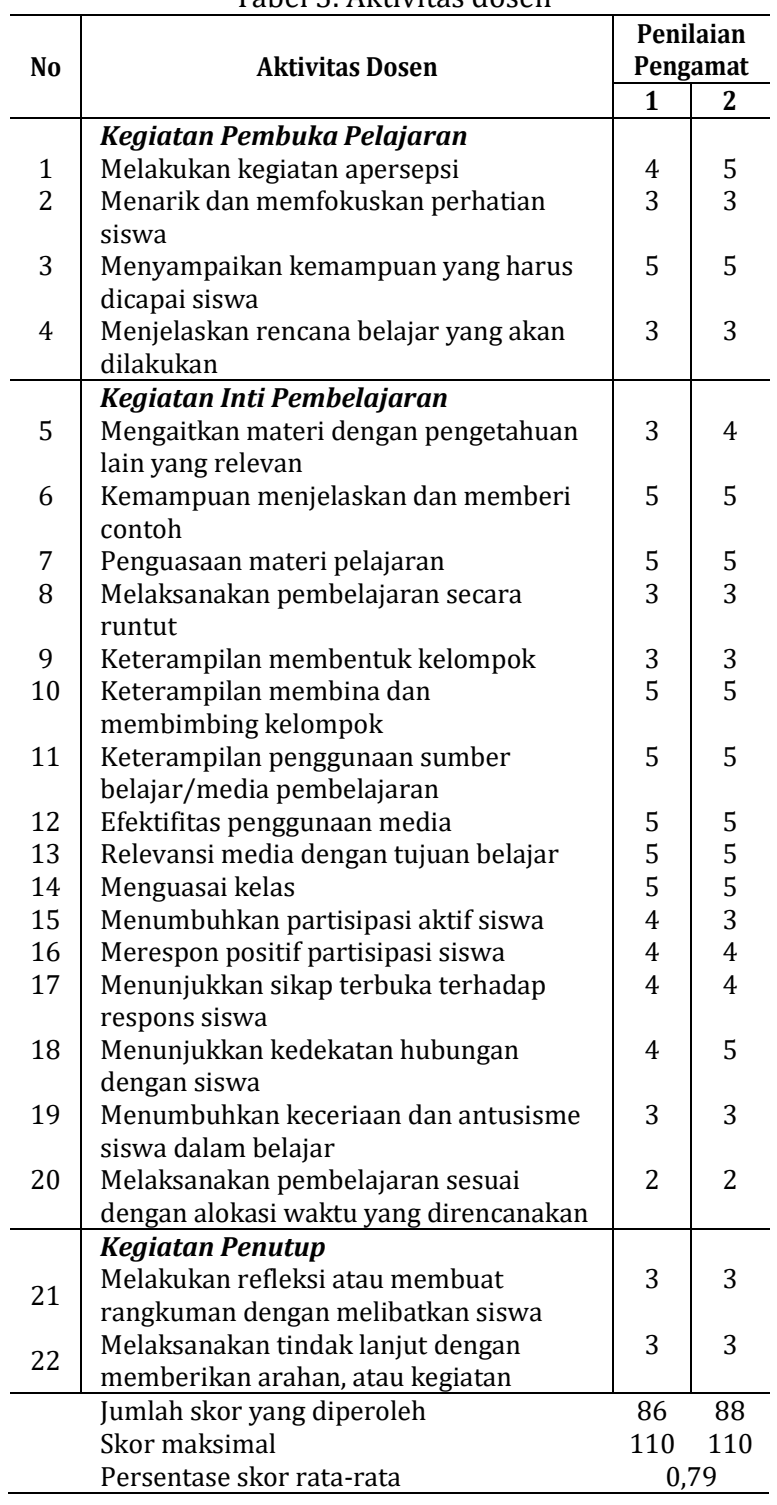

Tabel 4. Aktivitas mahasiswa

\begin{tabular}{clc}
\hline No. & \multicolumn{1}{c}{ Aktivitas yang diamati } & $\begin{array}{c}\text { Persentase } \\
\text { Aktivitas } \\
\text { Mahasiswa }\end{array}$ \\
\hline 1. & $\begin{array}{l}\text { Mendengarkan/memperhatikan pen- } \\
\text { jelasan dosen tentang materi pelajaran } \\
\text { dan kegiatan yang akan dilakukan }\end{array}$ & $85 \%$ \\
2 & Mengerjakan Lembar Kegiatan & $100 \%$ \\
& Mahasiswa & $100 \%$ \\
3 & Menggambar rancangan instalasi & $100 \%$ \\
4 & Memprogram rancangan instalasi & $20 \%$ \\
5 & Menyampaikan pendapat & $100 \%$ \\
7 & Mensimulasikan rancangan instalasi & $20 \%$ \\
& Aktivitas yang tidak relevan dengan \\
kegiatan belajar mengajar & $84 \%$ \\
\hline Persentase rata-rata aktivitas belajar & \\
\hline
\end{tabular}

Sedangkan Respon mahasiswa terhadap pembelajaran terangkum dalam Tabel 5. Dari hasil rekapitulasi data respon mahasiswa terlihat bahwa 
seluruh mahasiswa menyatakan setuju mengikuti pembelajaran menggunakan media pembelajaran simulasi komputer. Menurut mahasiswa, hal-hal yang membuat setuju enyenangkan adalah banyak prakteknya, gurunya menyenangkan, pengajaran tidak monoton dan tidak membosankan, pembelajaran elektronika digital membantu dalam menambah ilmu pengetahuan, mempunyai kesempatan bekerja dalam kelompok, suasana kelasnya menyenangkan, banyak memperoleh kesempatan mengeluarkan pendapat, mengerti tentang pemanfaatan pelajaran elektronika digital dalam praktek atau kehidupan sehari-hari serta banyak hal-hal baru yang belum pernah atau jarang ditemui (100\%).

Tabel 5. Rekapitulasi Respon Mahasiswa

\begin{tabular}{|c|c|c|}
\hline \multirow[t]{2}{*}{ Kriteria Respon } & \multicolumn{2}{|c|}{$\begin{array}{l}\text { Rekapitulas } \\
\text { Respon } \\
\text { Mahasiswa } \\
(\%)\end{array}$} \\
\hline & 1 & 0 \\
\hline $\begin{array}{l}\text { 1. Apakah kamu pernah belajar menggunakan } \\
\text { perangkat pembelajaran berbantuan simulasi } \\
\text { komputer? }\end{array}$ & 0 & 100 \\
\hline $\begin{array}{l}\text { 2. Apakah perangkat pembelajaran ini dapat } \\
\text { membantu kamu dalam proses pembelajaran } \\
\text { rangkaian digital? }\end{array}$ & 100 & 0 \\
\hline $\begin{array}{l}\text { 3. Apakah perangkat pembelajaran ini dapat } \\
\text { menumbuhkan nilai karakter jujur, kreatif } \\
\text { dan peduli? }\end{array}$ & 70 & 30 \\
\hline $\begin{array}{l}\text { 4. Apakah desain pada perangkat pembelajaran } \\
\text { ini menarik minat kamu untuk lebih giat lagi } \\
\text { dalam mempelajari rangkaian digital? }\end{array}$ & 80 & 20 \\
\hline $\begin{array}{l}\text { 5. Apakah isi perangkat pembelajaran } \\
\text { rangkaian digital ini menarik? }\end{array}$ & 80 & 20 \\
\hline $\begin{array}{l}\text { 6. Apakah topik yang ada pada perangkat } \\
\text { pembelajaran rangkaian digital ini kamu } \\
\text { jumpai dalam kehidupan sehari-hari? }\end{array}$ & 90 & 10 \\
\hline $\begin{array}{l}\text { 7. Apakah contoh-contoh yang disajikan dalam } \\
\text { perangkat pembelajaran rangkaian digital } \\
\text { ini mudah dipahami? }\end{array}$ & 80 & 20 \\
\hline $\begin{array}{l}\text { 8. Apakah kalimat dan kata dalam perangkat } \\
\text { pembelajaran rangkaian digital ini } \\
\text { diungkapkan secara lugas (tidak berbelit- } \\
\text { belit)? }\end{array}$ & 90 & 10 \\
\hline $\begin{array}{l}\text { 9. Apakah kamu bisa memahami bacaan yang } \\
\text { ada dalam perangkat pembelajaran } \\
\text { rangkaian digital ini? }\end{array}$ & 90 & 10 \\
\hline $\begin{array}{l}\text { 10. Apakah ilustrasi atau gambar yang ada pada } \\
\text { perangkat pembelajaran rangkaian digital } \\
\text { ini mudah dipahami? }\end{array}$ & 90 & 10 \\
\hline $\begin{array}{l}\text { 11. Apakah ilustrasi atau gambar yang ada pada } \\
\text { perangkat pembelajaran rangkaian digital } \\
\text { ini memperjelas materi? }\end{array}$ & 100 & 0 \\
\hline $\begin{array}{l}\text { 12. Apakah ukuran huruf pada perangkat } \\
\text { pembelajaran rangkaian digital ini sesuai } \\
\text { dengan kamu? }\end{array}$ & 100 & 0 \\
\hline $\begin{array}{l}\text { 13. Apakah dengan perangkat pembelajaran } \\
\text { rangkaian digital ini kamu dapat belajar } \\
\text { sendiri di rumah? }\end{array}$ & 80 & 20 \\
\hline $\begin{array}{l}\text { 14. Apakah perangkat pembelajaran ini memoti- } \\
\text { vasi kamu untuk lebih semangat belajar? }\end{array}$ & 90 & 10 \\
\hline $\begin{array}{l}\text { 15. Apakah perangkat pembelajaran ini berva- } \\
\text { riasi, tidak monoton, tidak membosankan, } \\
\text { dan merupakan hal yang baru bagi kamu? }\end{array}$ & 100 & 0 \\
\hline
\end{tabular}

Namun ada $10 \%$ siswa yang berpendapat bahwa guru menerangkannya kurang jelas, yang belum mengerti menjadi mengerti, 13,33\% siswa merasa tidak dapat belajar mandiri serta $6,67 \%$ siswa berpendapat bahwa LKS serta materi yang dibagikan menarik, $10 \%$ siswa berpendapat kurang memperoleh kesempatan bertanya kepada guru atau teman. Dari pengamatan selama proses pembelajaran berlangsung, ada beberapa siswa yang kurang paham dengan prosedur operasi software, yang membuat siswa berebut untuk bertanya. Karena berebut bertanya maka ada siswa merasa guru menerangkannya kurang jelas, kurang memperoleh kesempatan bertanya kepada guru atau teman serta tidak dapat belajar mandiri.

Sedangkan pendapat serta harapan siswa untuk pembelajaran dengan memanfaatkan simulasi komputer, siswa berpendapat pelajaran ini tidak terasa membosankan, pelajaran terasa semakin mudah serta LKS yang dibagikan mudah dipahami bahasanya. Namun ada 10\% yang berpendapat bahwa waktu pembelajaran terlalu pendek. Dari pengamatan selama proses pembelajaran berlangsung, kesulitan utama siswa adalah pemahaman prosedur operasi software dan juga kendala bahasa. Bisa dipahami kurangnya waktu pembelajaran karena siswa membutuhkan banyak waktu untuk menguasai hal-hal tersebut. Selanjutnya seluruh siswa berharap agar penggunaan simulasi komputer dapat berlanjut pada semester berikutnya, lebih banyak hal-hal baru yang menyenangkan selama pelajaran dan berharap agar pelaksanaan pembelajaran seperti ini tidak pernah kosong.

Respon siswa tersebut membuktikan bahwa penggunaan media pembelajaran simulasi komputer dapat menumbuhkan motivasi serta minat siswa. Berbagai kemudahan yang disediakan untuk melakukan berbagai macam kegiatan, baik program simulasi, buku siswa maupun LKS, terbukti mendapat respon positif dari siswa. Siswa senang dengan segala macam kegiatan hands-on dan minds-on, melalui percobaan virtual.

Sedangkan hasil Evaluasi terhadap perolehan skor dalam uji tes selama penelitian berlangsung diperoleh data hasil belajar seperti terlihat pada Tabel 6 .

Tabel 6. Perolehan Skor Pre-test dan Post-test No Nama Siswa Skor Awal Skor Akhir Ketuntasan

\begin{tabular}{cllll}
\hline 1. & Mhs 1 & $\mathbf{7 0 . 0 0}$ & $\mathbf{8 5 . 0 0}$ & Tuntas \\
2. & Mhs 2 & $\mathbf{7 0 . 0 0}$ & $\mathbf{8 5 . 0 0}$ & Tuntas \\
3. & Mhs 3 & $\mathbf{7 5 . 0 0}$ & $\mathbf{8 0 . 0 0}$ & Tuntas \\
4. & Mhs 4 & $\mathbf{8 0 . 0 0}$ & $\mathbf{8 5 . 0 0}$ & Tuntas \\
5. & Mhs 5 & $\mathbf{8 0 . 0 0}$ & $\mathbf{8 0 . 0 0}$ & Tuntas \\
6. & Mhs 6 & $\mathbf{7 0 . 0 0}$ & $\mathbf{8 0 . 0 0}$ & Tuntas \\
7. & Mhs 7 & $\mathbf{7 0 . 0 0}$ & $\mathbf{8 5 . 0 0}$ & Tuntas \\
8. & Mhs 8 & $\mathbf{7 0 . 0 0}$ & $\mathbf{8 5 . 0 0}$ & Tuntas \\
9. Mhs 9 & $\mathbf{8 0 . 0 0}$ & $\mathbf{9 5 . 0 0}$ & Tuntas \\
10. & Mhs 10 & $\mathbf{7 5 . 0 0}$ & $\mathbf{8 5 . 0 0}$ & Tuntas \\
11. Mhs 11 & $\mathbf{7 5 . 0 0}$ & $\mathbf{8 0 . 0 0}$ & Tuntas \\
12. Mhs 12 & $\mathbf{7 5 . 0 0}$ & $\mathbf{8 5 . 0 0}$ & Tuntas \\
13. Mhs 13 & $\mathbf{8 0 . 0 0}$ & $\mathbf{9 0 . 0 0}$ & Tuntas \\
14. Mhs 14 & $\mathbf{7 5 . 0 0}$ & $\mathbf{8 0 . 0 0}$ & Tuntas \\
15. Mhs 15 & $\mathbf{7 0 . 0 0}$ & $\mathbf{8 0 . 0 0}$ & Tuntas \\
16. Mhs 16 & $\mathbf{7 0 . 0 0}$ & $\mathbf{8 0 . 0 0}$ & Tuntas \\
17. Mhs 17 & $\mathbf{6 5 . 0 0}$ & $\mathbf{9 5 . 0 0}$ & Tuntas \\
18. Mhs 18 & $\mathbf{7 5 . 0 0}$ & $\mathbf{9 5 . 0 0}$ & Tuntas \\
19. Mhs 19 & $\mathbf{6 5 . 0 0}$ & $\mathbf{8 0 . 0 0}$ & Tuntas \\
20. & Mhs 20 & $\mathbf{6 5 . 0 0}$ & $\mathbf{7 5 . 0 0}$ & Tuntas \\
\hline
\end{tabular}


Tabel 6 menunjukkan rata-rata perolehan skor mahasiswa pada saat awal penggunaan simulasi komputer dan skor mahasiswa setelah menggunakan simulasi komputer. Berdasarkan keterangan kedua tabel di atas diperoleh informasi bahwa pada saat awal penilai hasil belajar mahasiswa terdapat 50\% mahasiswa yang masuk dalam kategori belum tuntas dalam belajar. Sedangkan pada saat akhir proses pembelajaran persentase mahasiswa belajar tuntas mencapai 100\%. Sehingga dapat dikatakan bahwa proses pembelajaran mahasiswa dengan menggunakan bantuan simulasi komputer telah membantu meningkatkan ketuntasan belajar mahasiswa.

Dengan bantuan SPSS 17, data skor ujian tengah semester dan ujian akhir semester yang diperoleh mahasiswa di atas dapat dideskripsikan pada Tabel 7.

Tabel 7. Deskripsi skor Pre-test \& Post-test

\begin{tabular}{lrr}
\hline & \multicolumn{1}{c}{ UTS } & \multicolumn{1}{c}{ UAS } \\
\hline $\mathrm{N} \quad$ Valid & 20 & 20 \\
$\quad$ Missing & 0 & 0 \\
Mean & 72.7500 & 84.2500 \\
Std. Deviation & 4.99342 & 5.68354 \\
Variance & 24.934 & 32.303 \\
Skewness & .024 & .801 \\
Std. Error of Skewness & .512 & .512 \\
Kurtosis & -.933 & -.002 \\
Std. Error of Kurtosis & .992 & .992 \\
\hline
\end{tabular}

Dari Tabel 7 diperoleh informasi bahwa telah terjadi peningkatan rata-rata skor mahasiswa dari skor ujian tengah semester $(72,75)$ hingga skor ujian akhir semester $(84,25)$.

Uji normalitas data digunakan menentukan teknik analisa data yang digunakan. Berdasarkan hasil uji normalitas data menggunakan SPSS 17, diperoleh keterangan Tabel 8, Gambar 2 dan Gambar 3.

\begin{tabular}{lrlllll}
\multicolumn{6}{c}{ Tabel 8. Hasil uji normalitas data } \\
\hline \multicolumn{5}{c}{ Kolmogorov-Smirnov ${ }^{\mathrm{a}}$} & \multicolumn{3}{c}{ Shapiro-Wilk } \\
& Statistic & Df & Sig. & Statistic & df & Sig. \\
\hline UTS & .209 & 20 & .122 & .887 & 20 & .124 \\
UAS & .248 & 20 & .102 & .847 & 20 & .105 \\
\hline
\end{tabular}

Berdasarkan Tabel 8, hasil tes normalitas data terhadap skor UTS dan skor UAS mahasiswa, diketahui bahwa signifikansi normalitas data skor UTS adalah 0.122. Ini berarti bahwa data skor hasil UAS mahasiswa berdistribusi normal (sig>0.05). Sedangkan hasil tes normalitas data terhadap skor UAS mahasiswa diketahui bahwa signifikansi normalitas data skor UAS adalah 0.102 . Ini berarti bahwa data skor hasil UAS mahasiswa juga berdistribusi normal (sig>0.05).

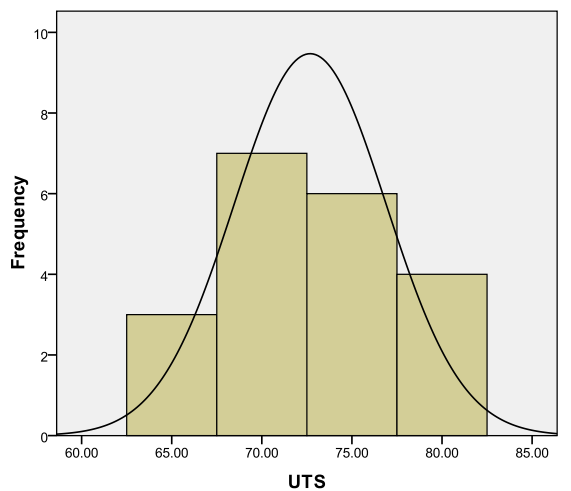

Gambar 2. Normalitas distribusi skor pre-test

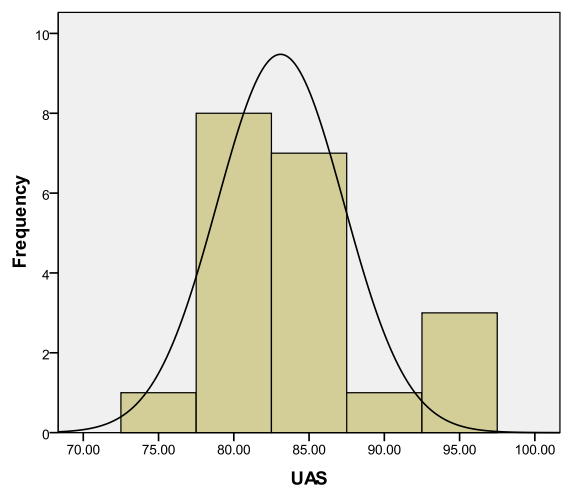

Gambar 3 Normalitas distribusi skor post-test

Berdasarkan hasil uji normalitas data skor hasil belajar mahasiswa maka ditentukan bahwa pengujian hipotesis data yang berdistribusi normal diuji dengan statistik parametrik. Signifikansi peningkatan hasil belajar mahasiswa diuji dengan teknik uji dua sampel berpasangan (correlated sample test).

Pengujian terhadap peningkatan perolehan skor mahasiswa prodi Teknik Komputer Universitas Maarif Hasyim Latif dideskripsikan pada Tabel 9.

Berdasarkan perolehan hasil ujian tengah semester menggunakan instrumen tes didapatkan hasil bahwa sebanyak 50\% mahasiswa masih belum tuntas dalam belajar. Dari pengamatan yang dilakukan selama perkuliahan berlangsung didapatkan bahwa kurang tuntasnya belajar mahasiswa karena masih belum tuntasnya seluruh materi ajar. Kompetensi yang harus dikuasai membutuhkan pengalaman yang cukup. Dengan kata lain dibutuhkan pengulangan contoh rancangan rangkaian digital agar mahasiswa terbiasa dengan hal-hal yang berhubungan dengan

Tabel 9. Hasil uji dua sampel berpasangan

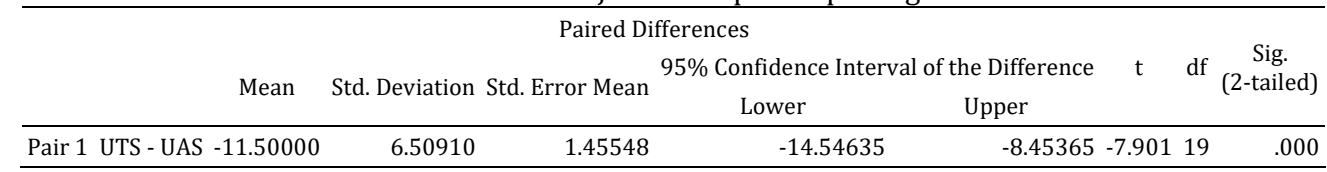


rangkaian system berbasis $r$.

Hasil uji dua sampel berpasangan yang terangkum pada Tabel 7 diperoleh hasil thitung $=$ 7.901. Sedangkan nilai $\mathrm{t}$ tabel pada tingkat signifikansi 0,05 dan derajat kebebasan 19, didapatkan $t_{\text {tabel }}=1.729$. Karena thitung $(7.901)$ lebih kecil daripada tabel (1.729) maka dapat disimpulkan bahwa terdapat perbedaan yang sangat signifikan kemampuan mahasiswa setelah dan sebelum penggunaan simulasi komputer dalam proses belajar mengajar

\section{PENUTUP}

Perangkat pembelajaran mata kuliah rangkaian digital berbantuan media simulasi komputer yang telah di buat layak untuk digunakan pada proses belajar mengajar di kelas untuk pembelajaran mata kuliah rangkaian digital .

Rencana Pembelajaran Semester (RPS) selama proses pembelajaran mata kuliah rangkaian digital berbantuan media simulasi komputer telah dilaksanakan oleh dosen pengampu dengan baik sesuai dengan yang direncanakan. Penerapan perangkat pembelajaran berpengaruh terhadap peningkatan hasil belajar mahasiswa mata kuliah rangkaian digital

\section{DAFTAR PUSTAKA}

Departemen Pendidikan Nasional. (2008). Kamus Bahasa Indonesia. In Cet. I. Jakarta: Pusat Bahasa Departemen Pendidikan Nasional.

Departemen Pendidikan Nasional RI. Peraturan Pemerintah Nomor 19 Tahun 2005 tentang Standar Nasional Pendidikan. , (2005).

Huitt, W. (2003). The psychomotor domain. Educational Psychology Interactive.

Nasution, S. (2003). Berbagai pendekatan dalam proses belajar dan mengajar. Jakarta: Bina Aksara.

Pemerintah R I. Undang-Undang No. 20 Tahun 2003 Tentang Sistem Pendidikan Nasional. , (2003).

Slameto. (2010). Belajar dan faktor-faktor yang mempengaruhinya. Jakarta: Rineka Cipta.

Sugiyono. (2011). Statistik Non Parametris untuk Penelitian. Bandung: Alfabeta.

Suharsimi, A. (2006). Dasar-dasar evaluasi pendidikan. Jakarta: Bumi Aksara.

Trianto. (2003). Model-model pembelajaran inovatif berorientasi Konstruktivistik. Jakarta: Prestasi Pustaka.

Winkel, W. S. (2007). Psikologi pengajaran. Yogyakarta: Gramedia. 